\title{
Expiration Date Effect on Mechanical and Chemical Properties of Glass Ionomer Cements
}

\author{
Efecto de La Fecha de Vencimiento sobre las Propiedades \\ Mecánicas y Químicas de los Cementos de lonómero de Vidrio
}

\author{
V. Zavala-Alonso; R. Jerónimo-Prieto; J. Ramírez-González; \\ G. Romo-Ramírez; M. Goldaracena-Azuara \& C. Ochoa-Monreal
}

ZAVALA-ALONSO, V.; JERÓNIMO-PRIETO, R.; RAMÍREZ-GONZÁLEZ, J.; ROMO-RAMÍREZ, G.; GOLDARACENA-AZUARA, M. \& OCHOA-MONREAL, C. Expiration date effect on mechanical and chemical properties of glass ionomer cements. Int. J. Odontostomat., 15(2):513-519, 2021.

\begin{abstract}
The glass ionomer cements (GICs) is a generic name given to a group of materials widely used in clinical dentistry which if used after the specified expiration date, material properties may be affected. to evaluate the Vickers microhardness, surface morphology and the energy dispersive X-ray microanalysis (EDX), of GICs with different expiration dates that were stored at room temperature. specimens of highly viscous glass ionomer cement (HVGIC) (Ketac Cem and Ketac Molar) and resin-modified glass ionomer cement (RMGIC) (Vitrebond) with different expiration dates (current, close to their expiration and expired) were prepared for Vickers microhardness test and scanning electronic microscopy (SEM) with EDX, measuring $5 \mathrm{~mm}$ in diameter and $2 \mathrm{~mm}$ length, per the manufacturer's instructions, in standard cylindrical teflon molds. For the comparison of obtained values, the ANOVA test was used, while Tukey test was used for the multiple comparisons. In all the GICs used, the microhardness decreased as the expiration date approached, finding a significant statistical difference $(\mathrm{P}<0.05)$ in Ketac Molar and Vitrebond. SEM sample analysis revealed similar cohesive cracks in all tested materials. The EDX analysis revealed the presence of the elements F, Al and Si in all GICs and Ca only in Ketac Molar and Ketac Cem. The elements were found in a higher atomic percentage in the GICs with an current date and in a lower percentage in those with an expired date. HVGIC and RMGIC with an expiration date finish and that were stored at room temperature, suffer significant physical and chemical changes, which could put doubts its clinical effectiveness.
\end{abstract}

KEY WORDS: glass ionomer cements, expiration date, mechanical and chemical properties, Vickers microhardness, scanning electron microscopy, energy dispersive X-ray microanalysis.

\section{INTRODUCTION}

Glass ionomer cements (GICs) were introduced by Wilson and Kent in 1970s (Shashibhushan et al., 2008). The glass ionomer is a generic name given to a group of materials widely used in clinical dentistry as teeth fillers and luting cements. GICs consist of poly acrylic acid and copolymers of poly acrylic acid as the ionomer and an acid decomposable fluoroaluminosilicate as the glass powders (Goenka et al., 2012). Biocompatibility, fluoride release, and chemical bonding to hard tissues of the tooth render it an ideal material in many restorative situations. Its ability to prevent and arrest carious lesions has been supported by numerous systematic reviews and meta-analyses (Tedesco et al., 2016; Raggio et al., 2016). GICs are widely used as the base, liner, luting, and restorative material (Saxena \& Tiwari, 2016). GICs being polymeric materials so it's in vitro and in vivo performance are associated to the chemical structural configuration and its rate of degradation and time. The degradation may be mainly chemical where a combination of effects arises from oxidative chain scission, oxidation hydrolysis, changes in crystallinity, and other factors that may be dependent on the environmental storage (Drummond, 2018). The vast majorities of the materials 
used in dentistry are perishable and have specific storage requirements to maintain optimum properties and maximize their shelf life. For example, unlike resin composite where manufacturers recommend refrigerated storage, for GICs it is only recommended not to store the product above $25^{\circ} \mathrm{C}$. When a dentist purchases any dental material, three important informations are printed on the box: the batch number, the expiration date, and the storage conditions. Most of dental materials have a limited shelf life, which is the time where a material retains the physical and mechanical properties necessary to accomplish its prescribed purpose (Sabbagh et al., 2018).

Although manufacturers encourage the professional to use dental materials within the useful life range indicated on the packaging, it is common for some operators to use them in periods close to the expiration date and even after expiration. Theoretically, if used after the specified expiration date, material properties may be affected. If viewed clinically, this may lead to failures such as difficulty in mixing the material, fractures, decementation, leakage, etc. In their daily practice, dentists may have some glass ionomers after the expiration date announced by the manufacturer, the question is should they discard these materials or can they continue to use them for a short period? The aim of this research was to evaluate the surface morphology, the energy dispersive X-ray microanalysis (EDX) and the Vickers microhardness of GICs with different expiration dates that were stored at room temperature. According to the literature search, this is the first investigation that analyzes and compares physical and chemical properties of GICs before their expiration versus expired. The null hypothesis was that there would be no differences in Vickers microhardness, chemical composition and surface morphology between the tested materials.

\section{MATERIAL AND METHOD}

The present study was carried out in the period between the months of August and September 2019. Autonomous University of San Luis Potosi Ethics Committee approved the research project grant CEIFE052-019. Preparation and evaluation of the samples was based on the methodology of Munguía-Moreno et al. (2018).

Sampler Preparation. GICs from the 3M company (packed in closed jars) of which, three highly viscous glass ionomer cement (HVGIC) (Ketac Cem) with different expiration dates; three HVGIC (Ketac molar) with different expiration dates and three resin-modified glass ionomer cement (RMGIC) (Vitrebond) too with different expiration dates, were used. According to their expiration date, the materials were divided into the following groups: current (CU), close to their expiration (CE) and expired (EX) (Table I). 10 specimens of each group were prepared for Vickers microhardness test and one for scanning electronic microscopy with EDX, measuring $5 \mathrm{~mm}$ in diameter and $2 \mathrm{~mm}$ length, the mixing of the materials was carried out following the powder-liquid ratios indicated by the manufacturer, using a paper block and a metal spatula, with the working time also suggested by the manufacturer, subsequently placing it in standard cylindrical teflon molds. Specimens were prepared between cellophane strips and glass slabs and light curing if needed with a LED.B (Woodpecker Medical Instrument Co., Ltd., Guilin, China).

Vickers Microhardness Test. The specimens for the microhardness test were stored at $37^{\circ} \mathrm{C}$ in distilled water for $24 \mathrm{hr}$. Vickers hardness measurements were made with a standard microhardness tester (Micro Vickers Hardness Tester HV-1000 DongGuan Sinowon

Table I. List of the tested materials and expiration date.

\begin{tabular}{llc}
\hline Material Group & \multicolumn{1}{c}{ Classification } & $\begin{array}{c}\text { Expiration date } \\
\text { (Year/month) }\end{array}$ \\
\hline Ketac Cem CU & Highly viscous glass ionomer cement & $2020 / 07$ \\
Ketac Cem CE & Highly viscous glass ionomer cement & $2019 / 10$ \\
Ketac Cem EX & Highly viscous glass ionomer cement & $2016 / 04$ \\
Ketac Molar CU & Highly viscous glass ionomer cement & $2021 / 02$ \\
Ketac Molar CE & Highly viscous glass ionomer cement & $2019 / 09$ \\
Ketac Molar EX & Highly viscous glass ionomer cement & $2018 / 05$ \\
Vitrebond CU & Resin modified glass ionomer cement & $2020 / 09$ \\
Vitrebond CE & Resin modified glass ionomer cement & $2019 / 09$ \\
Vitrebond EX & Resin modified glass ionomer cement & $2017 / 08$ \\
\hline
\end{tabular}

CU: Current; CE: Close to their expiration; EX: Expired. 
Precision Instrument Co., Ltd., South District, DongGuan, China). A diamond indenter was used with a load of $300 \mathrm{~g}$ for $15 \mathrm{~s}$. Each sample was submitted to three indentations located $200 \mathrm{~mm}$ far from each other, and the mean of the Vickers hardness number (VHN) was recorded. The diagonal length of the impressions was measured, and the VHN was calculated according to the standard formula $\mathrm{H}=1854 \mathrm{P} / \mathrm{d} 2$.

\section{Scanning Electron Microscopy (SEM) and EDX} microanalysis. For the surface morphology evaluation, the samples were viewed without dehydration and without gold coating under a scanning electron microscope (SEM) (JSM-6510, JEOL, Tokyo, Japan) at $10 \mathrm{kV}$ at $\times 33, \times 100, \times 300$ and $\times 3000$ of magnification. On the SEM, EDX was performance using Aztec Energy Analysis System \& Software (Oxford Instruments plc, UK) for elemental microanalysis. The EDX spectrums were collected from the sample surface, and elemental analysis (atomic \%) was performed. For each glass ionomer cement, EDX analysis was performed 10 times in different areas through a point analysis.

Statistical Analysis. Statistical analysis was carried out using the program IBM SPSS statistics V. 22 with one-way analysis of variance (ANOVA). Tests of differences between study groups were analyzed using the Tukey-Kramer test, and a value of $P<0.05$ was considered statistically significant for, VHN and EDX elemental microanalysis.

\section{RESULTS}

Vickers Microhardness. Graphical descriptive statistics of $\mathrm{VHN}$ are shown in Figure 1. For all the GICs, the highest $\mathrm{VHN}$ value was found in the CU group and the lowest VHN value was found in the EX group, statistically significant difference was found in Ketac molar HVGIC and Vitrebond RMGIC ( $P>0.05)$. Multiple comparisons were made between the study groups of the GICs where a statistical difference was found (Ketac molar and Vitrebond). A statistically significant difference was found for Ketac molar between CU study group versus $C E$ and $E X$ study groups. For Vitrebond RMGIC, statistically significant difference was found between CU versus EX study group (Table II).

Table II. Multiple comparisons of Vickers microhardness value between the study groups.

\begin{tabular}{ccc} 
Groups & Ketac Molar & Vitrebond \\
\hline CU vs CE & $.030^{*}$ & .074 \\
CU vs EX & $.002^{* *}$ & $.001^{* *}$ \\
CE vs EX & .150 & .292
\end{tabular}

CU: Current; CE: Close to their expiration; EX: Expired. * Statistically significant differences with $\mathrm{P}<0.05$.

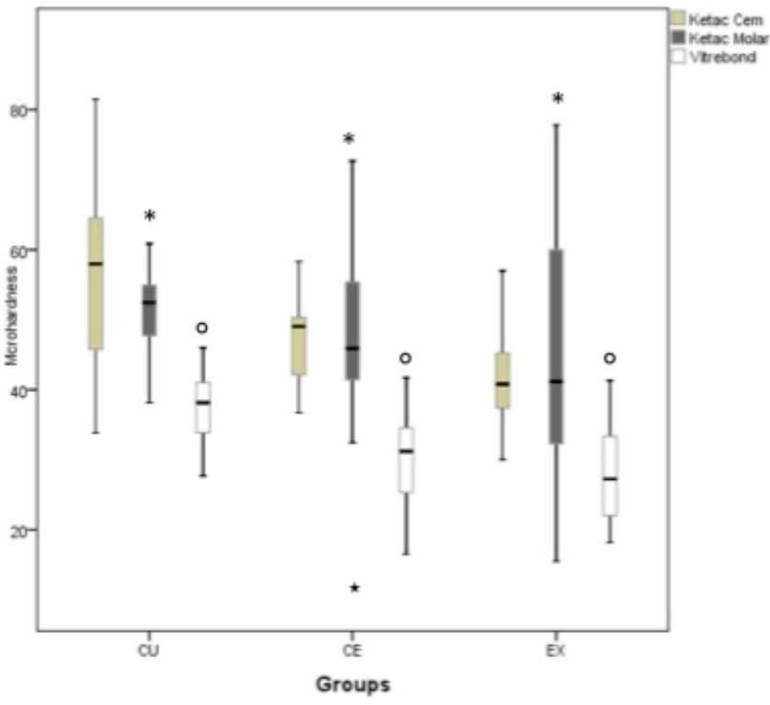

CU: Current; CE: Close to their expiration; EX: Expired. Equal symbols represent statistical difference with $\rho<0.05$ between groups.

Fig. 1. Box and whisker plots and comparisons of Vickers microhardness value between the study groups of each $\mathrm{GICs}$.
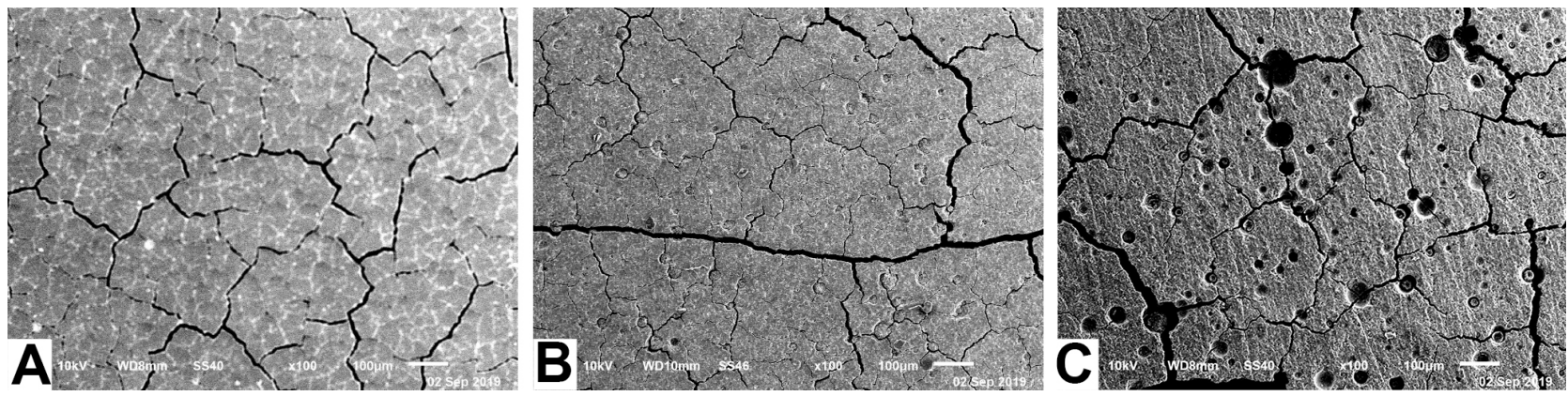

Fig. 2. Scanning electron microscopy micrographs at 100x of the Ketac Cem specimens: (A) Current (CU); (B) Close to their expiration (CE); (C) Expired (EX). 


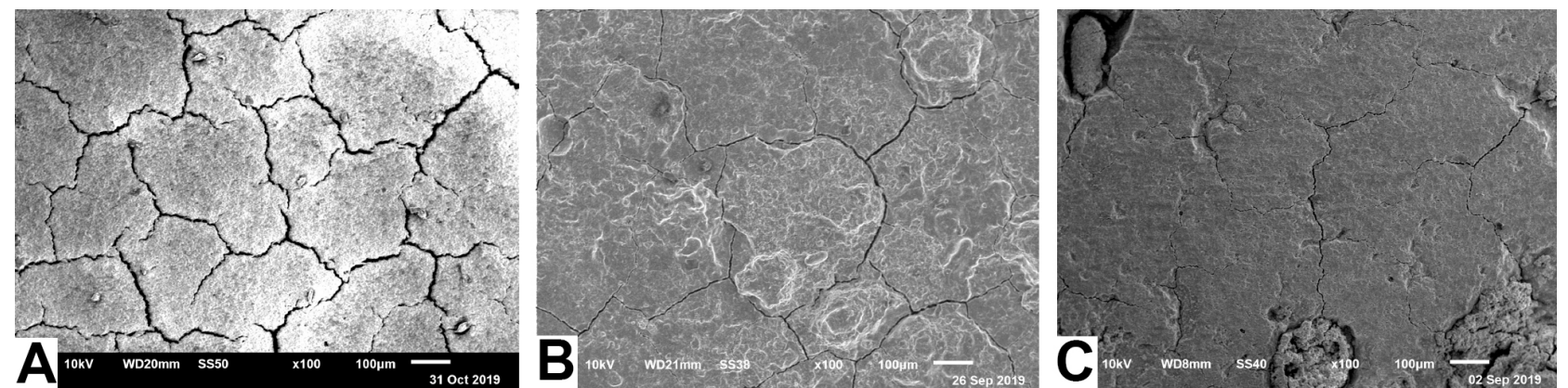

Fig. 3. Scanning electron microscopy micrographs at 100x of the Ketac Molar specimens: (A) Current (CU); (B) Close to their expiration (CE); (C) Expired (EX).
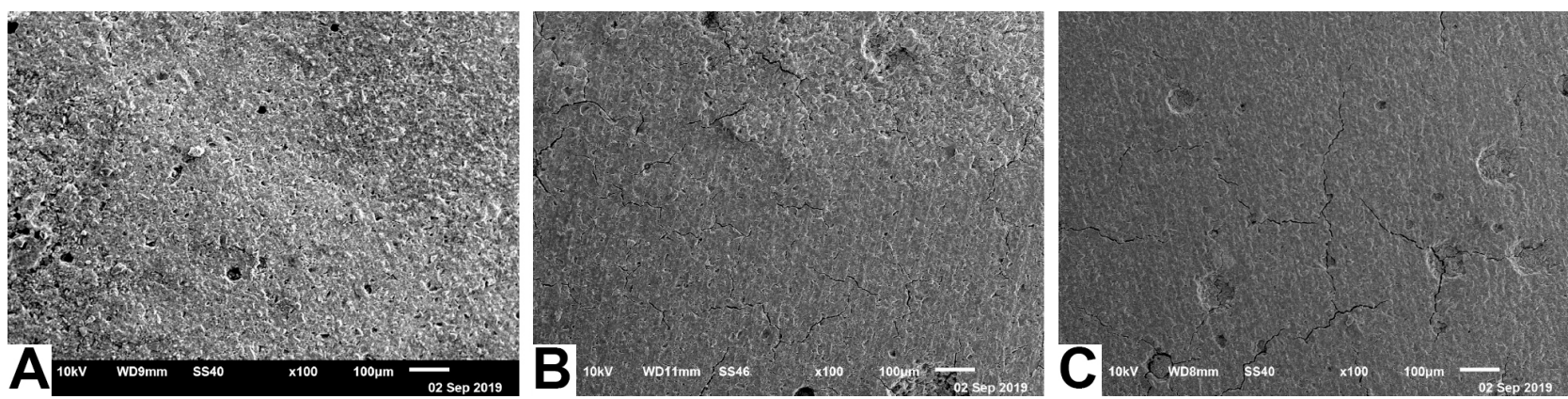

Fig. 4. Scanning electron microscopy micrographs at 100x of the Vitrebond specimens: (A) Current (CU); (B) Close to their expiration (CE); (C) Expired (EX).

Table III. Multiple comparisons of Atomic percentages of elements between the study groups of each GICs.

\begin{tabular}{|c|c|c|c|c|}
\hline \multicolumn{5}{|c|}{ KETAC CEM } \\
\hline \multicolumn{5}{|l|}{ Groups } \\
\hline & $\mathrm{F}$ & $\mathrm{Ca}$ & $\mathrm{Al}$ & Si \\
\hline$C U$ vs $C E$ & .589 & .578 & .946 & .165 \\
\hline CU vs EX & $.013^{*}$ & $.004^{*}$ & $.001^{*}$ & $.000^{*}$ \\
\hline$C E$ vs EX & .091 & $.005^{\star}$ & .212 & $.003^{*}$ \\
\hline \multicolumn{5}{|c|}{ KETAC MOLAR } \\
\hline & $\mathrm{F}$ & $\mathrm{Ca}$ & $\mathrm{Al}$ & Si \\
\hline$C U$ vs $C E$ & $.000^{*}$ & $.000^{*}$ & $.000^{*}$ & $.048^{*}$ \\
\hline$C U$ vs EX & $.000^{*}$ & $.001^{*}$ & $.000^{*}$ & $.004^{*}$ \\
\hline$C E$ vs EX & .994 & .960 & $.005^{*}$ & $.021^{*}$ \\
\hline \multicolumn{5}{|c|}{ VITREBOND } \\
\hline & $F$ & $\mathrm{Ca}$ & $\mathrm{Al}$ & Si \\
\hline$C U$ vs $C E$ & .198 & -- & $.020^{*}$ & $.000^{*}$ \\
\hline$C U$ vs EX & $.012^{*}$ & -- & $.000^{*}$ & $.000^{*}$ \\
\hline$C E$ vs EX & .388 & -- & .200 & .991 \\
\hline
\end{tabular}

CU: Current; CE: Close to their expiration; EX: Expired. * Statistically significant differences with $\mathrm{P}<0.05$.

SEM and EDX microanalysis. Figures 2 to 4 shows SEM images of each of the GICs in their different study groups, which show very similar surface features. The relatively homogeneous and flat surface of glass ionomer is clearly observed with the presence of pores, microcracks and air voids in the surface. Only the Ketac cem sample expires, presented a higher number of pores compared to the other samples of the same material (Fig. 2-c).

Figure 5 show graphical descriptive statistics of atomic percentages and comparisons of main constituents (elements) between the study groups of each GICs. Table III shows multiple comparisons of atomic percentages of elements between the study groups of each GICs. The main elements found in all the GICs were fluorine, aluminum and silica; calcium was observed only in the GIC Ketac Cem and Ketac Molar, all of them presented variation in their atomic percentage in the different study groups, with a statistically significant difference ( $P$ $<0.05)$. Atomic percentages of element fluorine were higher than that of other elements in Ketac Cem and Ketac Molar GCls and their study groups, in Vitrebond GIC, Atomic percentage of element Silica were higher than that of other elements. It was observed that the highest means in all the elements found in all GICs were presented in the CU group followed by the CE and finally the EX group. 

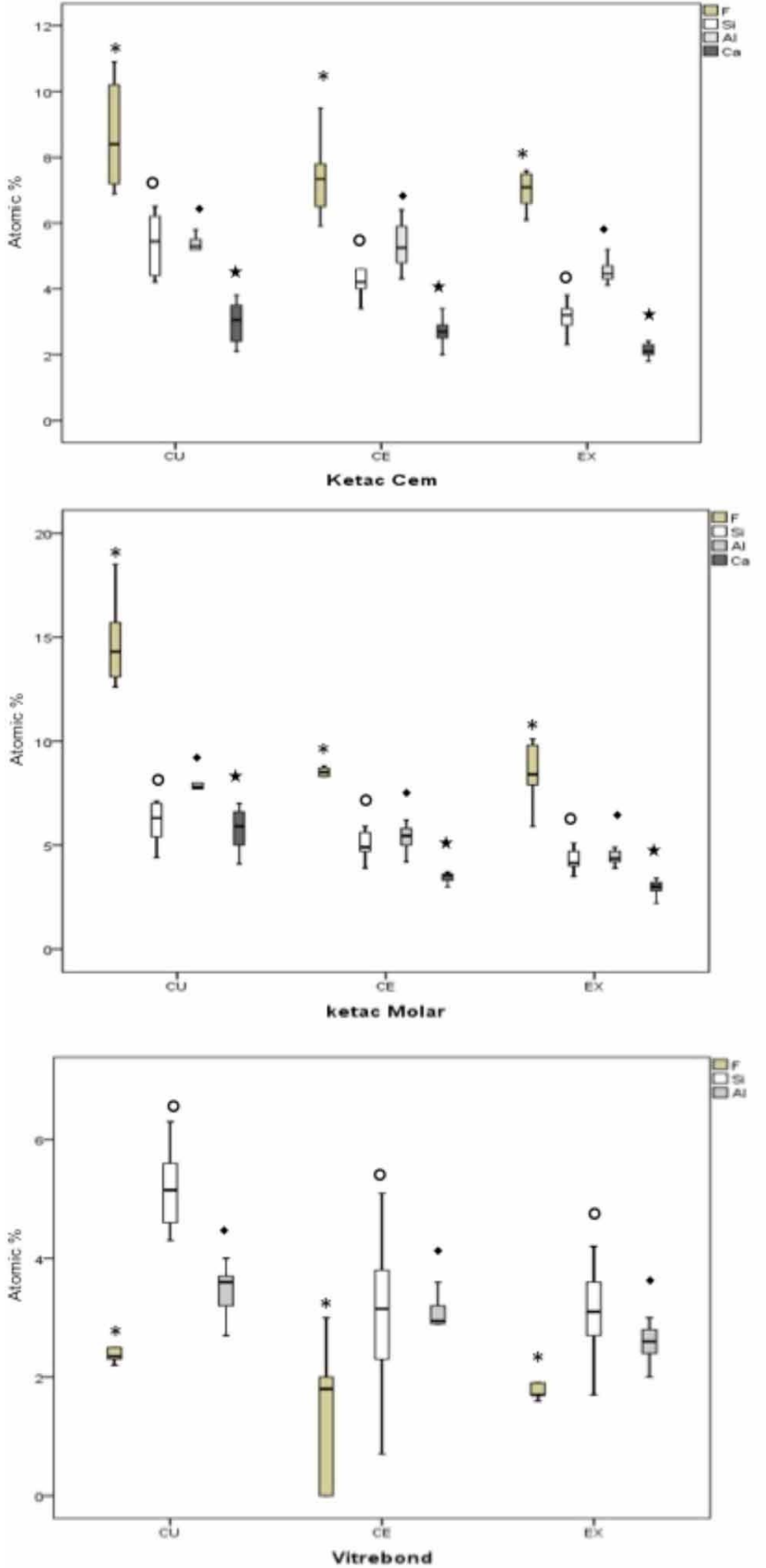

CU: Current: CE: Close to their expiration; EX: Expired; SD: standard deviation. Equal symbois represent statistical difference with $P<0.05$ between groups.

Fig. 5. Box and whisker plots of atomic percentages and comparisons of main constituents (elements) between the study groups of each GICs.

\section{DISCUSSION}

In the present study, three types of glass ionomers were evaluated (two with high viscosity and one modified with resin), each of which had 3 different expiration dates. According to our literature search, this is the first investigation that analyzes and compares the microhardness and chemical composition of GICs before their expiration against expired. Brinell, Rockwell, Shore, Vickers and Knoop test methods can be used to measure the hardness of dental materials (Baloch et al., 2010). Although the Knoop's method is most commonly used method, due to availability of equipment, the Vickers test method was used in this study, which was also used in other relevant studies (Shintome et al., 2009; Bala et al., 2012).

The microhardness values of the all GICs studied close to their expiration (CE) and of the expired ones (EX) were lower than the current specimens (CU) with significant statistical difference in Ketac Molar and Vitrebond. It can be assumed that the GICs behavior as well as composite may be more affected by the organic fraction of the material. In fact, the fillers are relatively inert inorganic materials; however, the coupling agents are themselves prone to hydrolysis through ester linkage within the molecules or siloxane links that are formed with the filler particle (Santerre et al., 2001; Sabbagh et al.). As the filler surface degrades, stress transfer will tear away the coupling agent from the filler surface, causing complete debonding (D'Alpino et al., 2016). The two high viscosity glass ionomer (HVGI) used in this study, had higher microhardness values compared to resin modified glass ionomer (RMGI), these results agree with those reported by Wang et al. (2007).

Theoretically, HVGI are supposed to have a better mechanical behavior than RMGI used to liner/ base material, due to their lower percentage of monomers. Similar results were presented in another study where the microhardness of filled composite against flowable composites was evaluated (Sabbagh et al.). Other important factors that affect the longevity and the stability of RMGI are the photoinitiator, the stabilizers, and the polymerization inhibitors incorporated in the resin matrix. Any alteration of those components will affect negatively the polymerization of the material and thus its properties (Hondrum \& Fernandez Jr., 1997). All the materials used in this study were stored outdoors with an average temperature between 20 and 35 oC. Fallo et al. (1996) studied the effects of uncontrolled outdoor storage on the polymerization, manipulation, and appearance of visible light-cured composite resin and resin-modified glass ionomer materials. Results showed that polymerization of all materials tested was apparently unaffected to any significant clinical degree by outdoor storage at 
temperatures ranging from $20^{\circ} \mathrm{F}$ to $112^{\circ} \mathrm{F}$ over 12 months. Regarding the surface morphology of the GIC samples observed in SEM, the surface morphology characteristics found in the GICs were the typical ones previously reported for these materials (cohesive cracks) (Swift Jr. \& Dogan, 1990; Lukomska-Szymanska et al., 2016; Salinovic et al., 2019). These findings can be attributed to the composition of the GICs, which contain a very low filling load as occurs in other dental materials (Lukomska-Szymanska et al.), as well as dehydration of the specimens when analyzed in SEM, however, this procedure was not performed in the present study (Ngo et al., 1997; Zafar \& Ahmed, 2015).

No notable differences were found between the different study groups of the Ketac Molar and the Vitrebond, which may suppose that the proximity to the date of manufacture of GIC did not causes significant changes in the topography of the surface, however, in the sample of the Ketac cem expired, a greater number of pores could be observed compared to the samples in force and close to the expiration date, this data coincides with a lower value of microhardness. In this same study group compared to the other study groups, the observed data can be attributed to the fact that the expiration date could cause problems during the mixing of the material, causing a cement with less homogeneity and therefore more porous and less hard. Sidhu \& Nicholson (2016) affirmed that the physical properties of glass-ionomer cements are influenced by how the cement is prepared, including its powder: liquid ratio, the concentration of the polyacid, the particle size of the glass powder and the age of the specimens. EDX is a reproducible, reliable, and precise technique to identify and quantify major components present in a material. Identification of constituents in materials leads to understanding of its various physical, biological, chemical, and mechanical properties.

The elements detected in each of the different GICs were the same reported in previous studies (Gu et al., 2005; Goenka et al.; Sabbagh et al.). In the present study, it was found that all the elements present in the different GICs decreased their atomic percentage as their expiration date approached, which is directly related to the decrease in the microhardness value. It was possible to observe a clear difference between the amount of the Fluorine element found between the HVGICs and the RMGIC, coinciding with several authors, being able to suppose that when presenting higher fluorine content, a greater liberation of this element in these materials will also occur (Francci, 1999; Cedillo Valencia, 2010). The results of Domarecka et al. (2015) show that changes in the chemical composition of resin-based materials, negatively affect their mechanical properties, as occurred in the present investigation. The results of this study suggest that the expiration date influences the chemical composition (atomic \%) and the microhardness value of high-viscosity and resin-modified glass ionomers, without affecting its surface morphology. Thus, the null hypothesis that there was no difference in the Vickers microhardness and chemical composition between the tested materials was accepted, the null hypothesis for surface morphology was rejected. Sabbagh et al. states that storing resin composites in a refrigerator helps to preserve their degradation, therefore, it is to be assumed that if the materials used here had been kept in refrigeration, the results would probably have been different. Other properties having clinical implication such as working time, consistency, and effect of ambient light should be investigated for a better understanding of the expiration date effect on GICs.

In conclusion, with the limitations of this study (in vitro study and lack of sealing of the jars containing the GICs), results reveal that highly viscous and resinmodified glass ionomers cements with an expiration date expired and that were stored at room temperature, suffer significant physical and chemical changes which could put doubts its clinical effectiveness. Currently, manufacturers do not specify measures to follow to extend or preserve the useful life of a $\mathrm{GCl}$. Therefore, storage stability should be prioritized more.

\section{ACKNOWLEDGMENTS}

This work was supported by Consejo Nacional de Ciencia y Tecnología (CONACYT CB-178261; CONACYT INF-00293390).

V. ZAVALA-ALONSO; R. JERÓNIMO-PRIETO.; J. RAMÍREZGONZÁLEZ.; G. ROMO-RAMÍREZ.; M. GOLDARACENAAZUARA. \& C. OCHOA-MONREAL. Efecto de la fecha de vencimiento sobre las propiedades mecánicas y químicas de los cementos de ionómero de vidrio. Int. J. Odontostomat., 15(2):513-519, 2021.

RESUMEN: El cemento de ionómero de vidrio (CIV) es un nombre genérico que se le da a un grupo de materiales ampliamente utilizados en odontología clínica que si se usan después de la fecha de vencimiento especificada, las propiedades del material pueden verse afectadas. evaluar la microdureza Vickers, la morfología superficial y el microanálisis de energía dispersa de rayos X (EDX), de CIV con diferentes fechas de caducidad almacenados a temperatura ambiente. 
Muestras de cemento de ionómero de vidrio de alta viscosidad (CIVAV) (Ketac Cem y Ketac Molar) y cemento de ionómero de vidrio modificado con resina (CIVMR) (Vitrebond) con diferentes fechas de vencimiento (vigente, próximo a su vencimiento y vencido) de $5 \times 2 \mathrm{~mm}$, fueron preparadas para microscopía electrónica de barrido (MEB) con EDX y microdureza Vickers, según las instrucciones del fabricante, en moldes de teflón cilíndricos estándar. Para la comparación de los valores obtenidos se utilizó la prueba ANOVA, mientras que para las comparaciones múltiples se utilizó la prueba de Tukey. En todos los CIV utilizados, la microdureza disminuyó a medida que se acercaba la fecha de vencimiento, encontrándose una diferencia estadística significativa ( $P$ $<0.05)$ en Ketac Molar y Vitrebond. El análisis de la muestra en MEB reveló grietas cohesivas similares en todos los materiales probados. El análisis EDX reveló la presencia de los elementos F, Al y Si en todos los GIC y Ca solo en Ketac Molar y Ketac Cem. Los elementos se encontraron en mayor porcentaje atómico en los GIC con fecha vigente y en menor porcentaje en aquellos con una fecha vencida. Los CIVAV y CIVMR con fecha de caducidad vencida y que fueron almacenados a temperatura ambiente, sufrieron cambios físicos y químicos importantes, lo que podría poner en duda su efectividad clínica.

PALABRAS CLAVE: cementos de ionómero de vidrio, fecha de caducidad, propiedades mecánicas y químicas, microdureza Vickers, microscopía electrónica de barrido, microanálisis de energía dispersa de rayos $X$.

\section{REFERENCES}

Bala, O.; Arisu, H. D.; Yikilgan, I.; Arslan, S. \& Gullu, A. Evaluation of surface roughness and hardness of different glass ionomer cements. Eur. J. Dent., 6(1):79-86, 2012.

Baloch, F.; Mirza, A. \& Baloch, D. An in-vitro study to compare the microhardness of glass ionomer cement set conventionally versus set under ultrasonic waves. Int. J. Health Sci. (Qassim), 4(2):149-55, 2010.

Cedillo Valencia, J. D. J. Ionómero de Vidrio de alta densidad como base en la técnica restauradora de Sandwich. A. D. M., 68(1):39-47, 2010.

D'Alpino, P. H.; Svizero, N. R.; Bim Júnior, O.; Valduga, C. J.; Graeff, C. F. \& Sauro, S. Effects of age condition on the distribution and integrity of inorganic fillers in dental resin composites. Clin. Oral Investig., 20(5):1011-9, 2016.

Domarecka, M.; Sokoowski, K.; Krasowski, M.; ukomska-Szymanska, M. \& Sokoowski, J. The shrinkage stress of modified flowable dental composites. Dent. Med. Probl., 52(4):424-33, 2015.

Drummond, J. L. Degradation, fatigue, and failure of resin dental composite materials. J. Dent. Res., 87(8):710-9, 2008.

Fallo, G. J.; Wakefield, C. W. \& Czerw, R. J. Effects of uncontrolled outdoor storage on the polymerization, manipulation, and appearance of visible light-cured composite resin and resin-modified glass ionomer materials. Mil. Med., 161(5):290-3,1996.

Francci, C.; Deaton, T. G.; Arnold, R. R.; Swift Jr., E. J.; Perdigão, J. \& Bawden, J. W. Fluoride release from restorative materials and its effects on dentin demineralization. J. Dent. Res., 78(10):1647-54, 1999.

Goenka, S.; Balu, R. \& Sampath Kumar, T. S. Effects of nanocrystalline calcium deficient hydroxyapatite incorporation in glass ionomer cements. J. Mech. Behav. Biomed. Mater., 7:69-76, 2012.

Gu, Y. W.; Yap, A. U.; Cheang, P. \& Khor, K. A. Effects of incorporation of $\mathrm{HA} / \mathrm{ZrO}(2)$ into glass ionomer cement (GIC). Biomaterials, 26(7):71320, 2005.
Hondrum, S. O. \& Fernandez Jr., R. The storage stability of dental composite resins: seven-year results. Gen. Dent., 45(4):382-9,1997.

Lukomska-Szymanska, M.; Kleczewska, J.; Nowak, J.; Prylinski, M.; Szczesio, A.; Podlewska, M.; Sokolowski, J. \& Lapinska, B. Mechanical properties of calcium fluoride-based composite materials. BioMed Res. Int., 2016:2752506, 2016.

Munguía-Moreno, S.; Martínez-Castañón, G. A.; Patiño-Marín, N.; CabralRomero, C. \& Zavala-Alonso, N. V. Biocompatibility and surface characteristics of resin-modified glass ionomer cements with ammonium quaternary compounds or silver nanoparticles: An in vitro study. J. Nanomater., 2018:6401747, 2018.

Ngo, H.; Mount, G. J. \& Peters, M. C. A study of glass-ionomer cement and its interface with enamel and dentin using a low-temperature, highresolution scanning electron microscopic technique. Quintessence Int., 28(1):63-9,1997

Raggio, D. P.; Tedesco, T. K.; Calvo, A. F. \& Braga, M. M. Do glass ionomer cements prevent caries lesions in margins of restorations in primary teeth?: A systematic review and meta-analysis. J. Am. Dent. Assoc., 147(3):177-85, 2016.

Sabbagh, J.; Nabbout, F.; Jabbour, E. \& Leloup, G. The effect of expiration date on mechanical properties of resin composites. J. Int. Soc. Prev. Community Dent., 8(2):99-103, 2018.

Salinovic, I.; Stunja, M.; Schauperl, Z.; Verzak, Z.; Malcic, A. I. \& Rajic, V. B. Mechanical Properties of High Viscosity Glass lonomer and Glass Hybrid Restorative Materials. Acta Stomatol. Croat., 53(2):125-31, 2019.

Santerre, J. P.; Shajii, L. \& Leung, B. W. Relation of dental composite formulations to their degradation and the release of hydrolyzed polymeric-resin-derived products. Crit. Rev. Oral Biol. Med., 12(2):13651, 2001.

Saxena, S. \& Tiwari, S. Energy dispersive X-ray microanalysis, fluoride release, and antimicrobial properties of glass ionomer cements indicated for atraumatic restorative treatment. J. Int. Soc. Prev. Community Dent., 6(4):366-72, 2016.

Shashibhushan, K. K.; Basappa, N. \& Subba Reddy, V. V. Comparison of antibacterial activity of three fluorides- and zinc-releasing commercial glass ionomer cements on strains of mutans streptococci: an in vitro study. J. Indian Soc. Pedod. Prev. Dent., 26 Suppl. 2:S56-S61, 2008.

Shintome, L. K.; Nagayassu, M. P.; Di Nicoló, R. \& Myaki, S. I. Microhardness of glass ionomer cements indicated for the ART technique according to surface protection treatment and storage time. Braz. Oral Res., 23(4):439-45, 2009.

Sidhu, S. K. \& Nicholson, J. W. A Review of glass-ionomer cements for clinical dentistry. J. Funct. Biomater., 7(3):16, 2016.

Swift Jr., E. J. \& Dogan, A. U. Analysis of glass ionomer cement with use of scanning electron microscopy. J. Prosthet. Dent., 64(2):167-74, 1990.

Tedesco, T. K.; Bonifácio, C. C.; Calvo, A. F.; Gimenez, T.; Braga, M. M. \& Raggio, D. P. Caries lesion prevention and arrestment in approximal surfaces in contact with glass ionomer cement restorations - A systematic review and meta-analysis. Int. J. Paediatr. Dent., 26(3):16172, 2016.

Wang, X. Y.; Yap, A. U.; Ngo, H. C. \& Chung, S. M. Environmental degradation of glass-ionomer cements: a depth-sensing microindentation study. J. Biomed. Mater. Res. B Appl. Biomater., 82(1):1-6, 2007.

Zafar, M. S. \& Ahmed, N. Therapeutic roles of fluoride released from restorative dental materials. Fluoride, 48(3):184-94, 2015.

\section{Corresponding autor:}

V. Zavala-Alonso

Facultad de Estomatología

Universidad Autónoma de San Luis Potosí

MÉXICO

E-mail: nveroza@fest.uaslp.mx 